\title{
Internal Control and the Financial Performance of Selected Deposit Money Banks Listed in Nigeria
}

\author{
${\text { Ogbebor, } \text { Peter }^{1 *} \quad \text { Osundina, Olawunmi }}^{2} \quad$ Oyamendan, Nathaniel $^{1}$ \\ 1. Department of Finance, School of Management Sciences, Babcock University, Ilishan-Remo, Ogun State \\ Nigeria \\ 2. Department of Economics, Varonical Adeleke School of Social Sciences, Babcock University Ilishan-Remo, \\ Ogun State Nigeria
}

\begin{abstract}
There is a general consensus that any organization without an Internal Control system in place is generally exposed to several threats that are capable of crumbling the organization in less or no time. Prominent amongst such threats are: Problem of incorrect financial statement and loss of the company's assets; stealing and mismanagement of organizational vital documents which may be done by an employee to take undue advantage. This study investigated the impact of internal control on financial performance covering the period of 10 years (2009-2018).The study employed an ex-post facto research design which is based on secondary data obtained from the fifteen (15) selected deposit money banks listed in Nigeria stock exchange. Pooled regression analysis was used while an inference were drawn at 5\% significant levelThe study findings showed that board independence is positive but insignificant to financial performance $(\beta=0.021 ; \mathrm{P}-$ value $>0.05)$. More so, on compliance with $\mathrm{CBN}$ regulatory framework have positive and significant influences on the financial performance $(\beta=0.051 ; \mathrm{P}$-value $<0.05)$, Furthermore, risk management is negatively but insignificant influences the financial performance of listed Deposit Money Banks in Nigeria $(\beta=-0.002$; P-value $<0.10)$ while internal communication of information positively and significantly influences the financial performances of listed Deposit Money Banks in Nigeria $(\beta=0.820 ; \mathrm{P}-$ value $<0.05)$ The study concluded that there is insignificant effect of internal control on the financial performances of listed Deposit Money Banks in Nigeria. The study recommended that banks must have an independent Board of Directors and its committee as a Corporate Governance regulatory requirement. Besides this, an independent audit department that is well trained and staffed should be set in all the branches of the banks to facilitate effective implementation of internal controls.
\end{abstract}

Keywords: Corporate governance, Deposit money banks, Financial performance, Internal control, Nigeria.

DOI: $10.7176 / \mathrm{DCS} / 10-4-07$

Publication date: April $30^{\text {th }} 2020$

\section{Introduction}

A number of financial scandals have been witnessed in listed companies in both in local and international organizations. In United States of America, investors lost \$180 billion (N24.84 trillion) in World Com Scandal of 2002, \$150 million (N20.7 Billion) in Tyco Scandal of 2002, \$1.4 billion (N193 billion) in Health South Scandal of 2003 (the largest publicly traded company) and \$3.9 billion in America international Group (AIG) scandal of 2005, investors lost $\$ 64.8$ billion in the Bernie Madoff Scandal (who orchestrated the biggest Ponzi scheme in history) of 2008 among several financial fraudulent activities affecting publicly quoted companies. Also, in the early 2000s, a number of high-profile corporate accounting scandals resulted in some investors, company personnel and other stakeholders suffering significant losses. These scandals resulted in demands for a greater emphasis on corporate governance. Therefore, in July 2002, the United States Congress passed the Sarbanes-Oxley Act (SOX) in an effort to lessen public concern over a number of high profile corporate disasters in the United States. Ashbaugh-Skaife (2008) documented that firms reporting internal control weaknesses have more complex operations; have experienced recent changes in organizational structure; are at increased exposure to accounting risks; and have fewer resources to invest in internal control. Hamersley, (2007) showed a negative market reaction to firms that had reported material weaknesses in internal control per the requirement of Sarbanes-Oxley Act Section 302.

Cases of poor financial performance in Nigeria Banking System is growing at an alarming rate, principally because the major perpetrators are internal staff and some corrupt members of the top management, this fact was also supported by the studies of Nwaze (2009), Okpara (2009), CBN report (2012) who emphatically stated that no fraud will be successful without the input of management employees. Sanusi (2012) made a presentation on the state of some banks operations and provided the sordid details of a number of the banks. Five prominent banks (Afribank Plc, Finbank Plc, Union Bank Plc, Intercontinental Bank Plc and Oceanic Bank Plc) were declared insolvent, chronically illiquid, with the revelation that they had largely eroded their shareholders' funds and practically breached all the ratios in banking. CBN unfolded the list of debtors comprising companies and their directors who secured loans worth N747 billion from the affected banks. It was amazing that some auditors certified these banks financials statements which were presented to shareholders at the annual general meetings; 
fail to disclose their debt portfolio. Quite surprisingly, PriceWaterhouse Coopers and Akintola Williams Delliote were the auditors of the five troubled banks.

In the accounting and auditing parlance, internal control is used to refer to a process of ensuring efficiency in organization's structure, work and authority flows, people, and management information systems, designed to help the organization accomplish specific goals or objectives. It is the process by which an organization's resources are directed, monitored, and measured. Internal control plays a vital role in preventing and detecting fraud and protecting the organization's resources, both physical (e.g., machinery and property) and intangible (e.g., reputation or intellectual property such as trademarks). At the level of the organization, internal control objectives relate to the accuracy and reliability of financial reporting, timely feedback on the achievement of operational or strategic goals, and compliance with laws and regulations. At the transaction level, internal control refers to the actions taken in order to achieve a specific objective (precisely, how to ensure the organization's payments to third parties are for valid services rendered). Internal control procedures reduce process variation, leading to more predictable outcomes (Kieso, 2010).

In the United States of America, the Committee of Sponsoring Organization (COSO) framework identifies five main elements of internal control systems against which the review should take place; these elements of control help organizations to improve performance (COSO 2013). These include Control environment, Risk assessment, control activities, information and communication and monitoring. It also includes the policies and procedures that protect the assets of an organization, create dependable financial reporting, uphold compliance with laws and regulations and achieve efficient and effective operations. These are not only linked to accounting and reporting but also to the organizations communication processes, both internally and externally, which include methods for handling funds received and expended by the organization, preparing appropriate and timely financial reporting to board members and officers, conducting the annual audit of the organization's financial statements, maintaining of real and other properties and their physical existence. They also included the risk assessment and analysis of the control environment (Brennan \& Soloman, 2008). There is a general anticipation that institution and implementation of proper internal control systems will always lead to improved financial performance. The COSO framework also established that a properly instituted system of internal control improves the reporting process and also gives rise to accurate and reliable reports which enhances the accountability function of management of an entity. Internal controls are put in place to ensure the safe custody of all companies' assets; to avoid abuse, misuse or misappropriation of assets and to detect and safeguard company's resources against probable frauds.

There is a general consensus that any organization without an Internal Control system in place is generally exposed to several threats that are capable of crumbling the organization in less or no time (Ordu \& Uwaoma, 2015). Prominent amongst such threats are: Problem of incorrect financial statement and loss of the company's assets; stealing and mismanagement of organizational vital documents which may be done by an employee to take undue advantage. There is also the issue of incorrect and unreliable financial records which may lead to loss of organizational integrity; non implementation of accounting policies in consistent with the applicable legislation appropriate in presentation of financial statement as well as non-adherence of annual budgets and implementation of planning policies. As indicated in the Central Bank of Nigeria Banking Sector Report, the health of financial system depends to a larger extent on the soundness of financial institutions, particularly, the commercial Banks (CBN, 2012).

Several studies have been conducted on the factors influence the earning of firms in the banking industry (Adegboye, Olowe \& Uwuigbe, 2013). Ani and Ugwuanyi, 2012 opined that internal factors impact significantly on the banks profitability. It was reported that overall operational efficiency is a key determinants of banks' performance in Nigeria. These operational efficiency factors constitute cost efficiency, solvency status, quality of assets and capital adequacy. Akwaa-Sekyi and Moreno (2016) have shown that weak ethical practices, management policies and integrity issues (control environment), lack of proper evaluation mechanisms of procedures and policies (monitoring), poor risk assessment and lack proper ways of receiving, disseminating and acting on information (information and communication) has led to increased fraud in organizations and this results to low financial performance. Thus this study would explore ways in which Board of directors, internal communication and risk management system in the Bank can be used as means to improve the profit in the Banking industry.

Based on the problem identified, this research therefore sets out to investigate the effect of internal control on financial performance of Banks using the elements of the COSO framework.

\subsection{Literature Review}

\subsection{Internal Control}

Internal control system has been defined to mean various things in the past. Morris (2011) separates internal controls into those that are general (entity-wide) controls from those that are specific (account-level) controls. He believes that if management was overriding control features in order to manage earnings, then one would expect 
to find more Internal Control Weaknesses related to general controls, even if the specific (account-level) controls are effective.

According to Kirsch, (2002) Internal control can be defined as a set of mechanism designed to motivate an individual or a group towards achievement of a desired objectives while, Ouchi (1979) stated that internal control must be able to achieve the objective of bringing about cooperation among people with divergent objectives in an organization. Similarly, International Standard on Auditing (ISA 400) defines internal control as all policies and procedure adopted by the management of an entity to assist in achieving the primary objectives of the management by make sure the business is conducted in the most possible efficient way and also ensuring strict adherence to management policies, safeguarding of asset, prevention and detection of fraud and timely preparation of reliable account.

However, in this study, internal control is defined in reference to the Committee of Sponsoring Organizations of the Treadway Commission (COSO). Internal control is a process, effected by an entity's board of directors, management, and other personnel designed to provide a reasonable assurance regarding the achievement of objectives relating to operations, reporting and compliance (COSO 2014). The 2013 Framework states, "A system of internal control over financial reporting is designed and implemented to prevent or detect, in a timely manner, a material omission from or a misstatement of the financial statements due to error or fraud. The COSO framework for internal control has five components as Control activities, monitoring, control environment and information communication (COSO Integrated Framework 2013).

\subsection{Financial Performance}

Financial performance measures the extent of achievements by organisations, which could reflect a good result for certain periods and otherwise for other periods (Batchimeg, 2017). One of the main aim for measuring the achievements of organisations is to obtain useful information related to flow of fund, the use of fund, effectiveness, and efficiency in the utilization of the funds. This information also motivates managers to make good informed decisions (Amal, Sameer, \& Yahya, 2012). Several measurements exists in literature on how to measure the financial performance of organisations. Some of the relevant ones have been described in this study as well as the argument for the selection of the measurement used in this study.

\section{Theoretical Framework}

The compatibility of the resource dependency theory and the stakeholders' theory is based on the assumption that the control of the board improves firm performance. Both theories argue that unique human capital provides effectiveness. Thereafter, effective control positively influences firm performance. Several studies are in accordance with the resource dependency theory and the stakeholder's theory. These studies found a positive relation between the level of control and firm performance (Carter, 2003 \& Kim, 2013). Because effective control encourages a better understanding of the market, increases creativity and innovation, and increases effectiveness of the board of directors by taking a broader view (Carter, 2003 and Kim, 2013).

Previous literature on the relationship between internal control and firm performance generally recognizes two theories: agency theory and stewardship theory (Nicholson \& Kiel, 2007). Agency theory, which dominates the firm theory and corporate governance literature, has its basis in the separation of ownership and management and the divergent interests between the two. As such, it requires control of management by boards of directors operating as agents for the owners. External directors are expected to be free from the influence of the firm's management, which allows them to perform their duties more effectively and provide more value than internal directors. Effective monitoring by independent directors is expected to lower agency costs and increase firm performance (Baysinger \& Butler 1985; Fama 1980; Jensen \& Meckling 1976; Lefort \& Urzua 2008). Therefore, according to this theory, board independence should be positively associated with firm performance. Despite substantial research, as discussed earlier, on the relationship between boards and firm performance, the extant empirical results are far from conclusive.

\section{Methodology}

The target population of the study is the 15 Banks listed on the Nigerian Stock Exchange as at as $31^{\text {st }}$ December, 2018. The study will cover a period of 10 years (2009-2018). Total enumeration sampling technique will be adopted for this study in selecting the sample subjects from the population elements. Only banks listed as at the beginning of the time frame of the study i.e. 2009 and still in operation as at date are considered as the sample of the study and all the banks possess the criteria for selection. Secondary data was employed for data collection, the data was extracted from published Annual Reports of the fifteen sampled banks.

\subsection{Model Specification}

$\mathrm{Y}=$ dependent variable $=$ financial performance measured as return on equity (ROE)

$\mathrm{X}=$ independent variable $=$ internal control system measured as risk management, board independence, 
compliance and internal communication)

$\mathrm{Y}=\mathrm{f}(\mathrm{X}, \mathrm{Z})$

$\mathrm{X}=\mathrm{x}_{1}, \mathrm{x}_{2}, \mathrm{x}_{3}, \mathrm{x}_{4}, \mathrm{X}_{5}, \mathrm{x}_{6}, \mathrm{x}_{7}, \mathrm{x}_{8}$

$\mathrm{Y}=\mathrm{ROE}$

$\mathrm{Z}=$ control variables $=\mathrm{z}_{1}, \mathrm{z}_{2}, \mathrm{z}_{3}, \mathrm{Z}_{4} \quad \mathrm{Z}=\mathrm{CAR}$ (Capital Adequacy Ratio), Liq (Liquidity Ratio), Size, Age $]$

$\mathrm{Y}=$ dependent variable $=$ financial performance measured as Return on equity (ROE)

$\mathrm{X}=$ independent variable $=$ Internal Control System measured as Risk management, Board independence,

Compliance and Internal communication)

$\mathrm{Y}=\mathrm{f}(\mathrm{X}, \mathrm{Z})$

$\mathrm{X}=\mathrm{x}_{1}, \mathrm{x}_{2}, \mathrm{x}_{3}, \mathrm{x}_{4}, \mathrm{x}_{5}, \mathrm{x}_{6}, \mathrm{x}_{7}, \mathrm{x}_{8}$

$\mathrm{Y}=\mathrm{ROE}$

$\mathrm{Z}=$ control variables $=\mathrm{z}_{1}, \mathrm{z}_{2}, \mathrm{Z}_{3}, \mathrm{Z4}[\mathrm{Z}=\mathrm{CAR}$ (Capital Adequacy ratio), LR (Liquidity ratio), Size, Age $]$

Main Functional Relationship:

$\mathrm{Y}=\mathrm{f}\left(\mathrm{x}_{1}, \mathrm{x}_{2}\right)$

$\mathrm{ROE}=\mathrm{f}(\mathrm{PENxD}, \mathrm{FoBM})$

$\mathrm{Y}=\mathrm{f}\left(\mathrm{x}_{3}, \mathrm{x}_{4}\right)$

$\mathrm{ROE}=\mathrm{f}($ FoCM, FoPR $)$

$\mathrm{Y}=\mathrm{f}\left(\mathrm{x}_{5}, \mathrm{x}_{6}\right)$

$\mathrm{ROE}=\mathrm{f}(\mathrm{NPL} / \mathrm{TL}, \mathrm{CIR})$

$\mathrm{Y}=\mathrm{f}\left(\mathrm{x}_{7}, \mathrm{x}_{8}\right)$

$\mathrm{ROE}=\mathrm{f}(\mathrm{D}, \mathrm{IC})$

The Models without and with control variables:

$\mathrm{ROE}_{\mathrm{it}}=\beta_{0}+\beta_{1} \mathrm{PENxD}_{\mathrm{it}}+\beta_{2} \mathrm{FoBM}_{\mathrm{it}}+\varepsilon_{\mathrm{it}}$

$\mathrm{ROE}_{\mathrm{it}}=\beta_{0}+\beta_{1} \mathrm{PENxD}_{\mathrm{it}}+\beta_{2} \mathrm{FoBM}_{\mathrm{it}}+\beta_{3} \mathrm{CAR}_{\mathrm{it}}+\beta_{4} \mathrm{LR}_{\mathrm{it}}+\beta_{5} \mathrm{FS}_{\mathrm{it}}+\beta_{6} \mathrm{Age}_{\mathrm{it}}+\varepsilon_{\mathrm{it}}$

$\mathrm{ROE}_{\mathrm{it}}=\beta_{0}+\beta_{1} \mathrm{FoCM}_{\mathrm{it}}+\beta_{2} \mathrm{FoPR}_{\mathrm{it}}+\varepsilon_{\mathrm{it}}$

$\mathrm{ROE}_{\mathrm{it}}=\beta_{0}+\beta_{1} \mathrm{FoCM}_{\mathrm{it}}+\beta_{2} \mathrm{FoPR}_{\mathrm{it}}+\beta_{3} \mathrm{CAR}_{\mathrm{it}}+\beta_{4} \mathrm{LR}_{\mathrm{it}}+\beta_{5} \mathrm{FS}_{\mathrm{it}}+\beta_{6} \mathrm{Age}_{\mathrm{it}}+\varepsilon_{\mathrm{it}}$

$\mathrm{ROE}_{\mathrm{it}}=\beta_{0}+\beta_{1} \mathrm{NPL} / \mathrm{TL}_{\mathrm{it}}+\beta_{2} \mathrm{CIR}_{\mathrm{it}}+\varepsilon_{\mathrm{it}}$

$\mathrm{ROE}_{i \mathrm{t}}=\beta_{0}+\beta_{1} \mathrm{NPL} / \mathrm{TL}_{\mathrm{it}}+\beta_{2} \mathrm{CIR}_{\mathrm{it}}+\beta_{3} \mathrm{CAR}_{\mathrm{it}}+\beta_{4} \mathrm{LR}_{\mathrm{it}}+\beta_{5} \mathrm{FS}_{\mathrm{it}}+\beta_{6} \mathrm{Age}_{\mathrm{it}}+\varepsilon_{\mathrm{it}}$

$\mathrm{ROE}_{i \mathrm{t}}=\beta_{0}+\beta_{1} \mathrm{D}_{\mathrm{it}}+\beta_{2} \mathrm{IC} \mathrm{C}_{\mathrm{it}}+\varepsilon_{\mathrm{it}}$

$\mathrm{ROE}_{\mathrm{it}}=\beta_{0}+\beta_{1} \mathrm{D}_{\mathrm{it}}+\beta_{2} \mathrm{IC}_{\mathrm{it}}+\beta_{3} \mathrm{CAR}_{\mathrm{it}}+\beta_{4} \mathrm{LR}_{\mathrm{it}}+\beta_{5} \mathrm{FS}_{\mathrm{it}}+\beta_{6} \mathrm{Age}_{\mathrm{it}}+\varepsilon_{\mathrm{it}}$

Where:

$\mathrm{x}_{1}=$ Proportion of Executive to Non-executive directors (PENxD)

$\mathrm{x}_{2}=$ Frequency of Board meetings $($ FoBM $)$

$\mathrm{x}_{3}=$ Number of times the risk management committee meets (FoCM)

$\mathrm{x}_{4}=$ Rendition of periodic reports (FoPR)

$\mathrm{x}_{5}=$ Ratio of performing loans to Non-performing loans (NPL/TL)

$\mathrm{x}_{6}=$ cost to income ratio (ratio of operating expenses to operating income) (CIR)

$\mathrm{x}_{7}=$ Disclosures of accounting policies in the financial statement (D)

$\mathrm{x}_{8}=$ Frequency of monitoring internal control deficiencies by the audit committee (IC)

$\mathrm{Z}_{1}=$ Capital Adequacy ratio (CAR)

$\mathrm{Z}_{2}=$ Liquidity ratio (LR)

$\mathrm{Z}_{3}=$ Firm Size (FS)

$\mathrm{Z}_{4}=$ firm Age (Age)

$\beta_{0}=$ Intercepts of equation; $\beta_{1}, \beta_{2}, \beta_{3}, \beta_{4}, \beta_{5}$, and $\beta_{6}$ are regression co-efficient for each of the independent variables and control variables.

\subsection{Results and Discussion}

\section{Inferential Statistics and Test of Hypotheses}

The overall objective of the study is to investigate the impact of internal control on financial performance of the listed banks in Nigeria. For this reason, the discussion based on the results from the static panel regression analysis which considers Random and Fixed effects regression models using Stata 15 was carried out in this subsection. To start with, we estimated a simple model which is also known as Pooled regression model. This model is also known as OLS. This is because the model serves as the basis of any other type of regression. However, the use of Fixed or Random effect model is based on the assumption that panel effect exists since we are using data that is cross-section and time series in nature. Among the three panel estimators; that are Pooled, Fixed and Random, the most appropriate model is chosen using Hausman or Breusch and Pagan Lagrangian multiplier (LM) test for random effects test or both. To first check whether panel effect exists in our data since we are considering panel data in this study; LM test is used. For LM test the null hypothesis is "variance across 
entities is zero'. In other words, it means there is no panel effect which also confirms applicability of Pooled (OLS) model. Furthermore, if the null hypothesis of zero variance across entities is rejected, then we move to Hausman test which can reliably show us a useful model between Random Effect Model and Fixed Effect Model. This tool basically tests whether the unique errors are correlated with the explanatory variables; the null hypothesis is they are not. Using this test, Random Effect model is preferred if the null hypothesis is accepted. That is, Random Effect model is preferred if the test statistic result is insignificant. In other words, rejection of the null hypothesis indicates that Random Effect Model is not appropriate.

To achieve the specific objectives in this study, we estimated four different regression equations. These for equations specified in the preceding chapter serve as base regression equations that accommodate the other explanatory variables which are known as control variables while forming another equations (equations with control variables) outlined in this subsection;

\section{Test of Hypothesis One ( $\left.\mathrm{H}_{01}\right)$}

Research Hypothesis (Ho1)

i: There is no significant effect of board independence (proportion of Executive to Non-executive directors and Frequency of meetings) on the financial performance of listed Banks in Nigeria.

ii: $\quad$ Capital Adequacy ratio, Liquidity ratio, firm size and firm age have no significant controlling effect on Compliance with regulatory framework (committee meetings and Periodic reports) and the financial performances of listed Deposit Money Banks in Nigeria

Table 3: Board Independence and Financial Performance

\begin{tabular}{|c|c|c|}
\hline VAR & $\begin{array}{c}\text { Pooled Regression wit } \\
\text { (1) } \\
\beta \text { (StdError) [t-stat] } \\
\text { \{p-value] } \\
\end{array}$ & $\begin{array}{c}\text { andard Error (Cluster) } \\
\text { (2) } \\
\beta \text { (StdError) [t-stat] } \\
\{\text {-value }\} \\
\end{array}$ \\
\hline PENxD & $\begin{array}{c}0.021(0.032)[0.665] \\
\{0.518\}\end{array}$ & $\begin{array}{c}-0.020(0.035)[-0.579] \\
\{0.573\}\end{array}$ \\
\hline FoBM & $\begin{array}{c}-0.136 * *(0.052)[-2.611] \\
\{0.022\}\end{array}$ & $\begin{array}{c}-0.144 * *(0.051)[-2.853] \\
\{0.014\}\end{array}$ \\
\hline CAR & & $\begin{array}{c}0.0001(0.0003)[0.410] \\
\{0.689\}\end{array}$ \\
\hline LR & & $\begin{array}{c}0.157 *(0.084)[1.882] \\
\{0.082\}\end{array}$ \\
\hline FS & & $\begin{array}{c}0.056 * * *(0.013)[4.406] \\
\{0.001\}\end{array}$ \\
\hline Age & & $\begin{array}{c}-0.0001(0.0005)[-0.132] \\
\{0.897\}\end{array}$ \\
\hline Constant & $\begin{array}{c}0.320 * * *(0.092)[3.490] \\
\{0.004\} \\
\end{array}$ & $\begin{array}{c}-0.853 * * *(0.214)[-3.982] \\
\{0.002\} \\
\end{array}$ \\
\hline $\begin{array}{l}\mathbf{N} \\
\text { R-squared } \\
\text { Adjusted R-squared } \\
\text { F-statistics }\{\text { P-value }\end{array}$ & $\begin{array}{c}140 \\
0.049 \\
0.036 \\
3.66\{0.046\}\end{array}$ & $\begin{array}{c}140 \\
0.139 \\
0.100 \\
24.10\{0.000\}\end{array}$ \\
\hline $\begin{array}{l}\text { LM Test }\{\text { P-value }\} \\
\text { Hausman Test }\{\text { P-value }\}\end{array}$ & $\begin{array}{l}0.03\{0.431\} \\
0.20\{0.905\}\end{array}$ & $\begin{array}{l}0.00\{1.000\} \\
1.89\{0.929\}\end{array}$ \\
\hline $\begin{array}{l}\text { Het. Test }\{\text { P-value }\} \\
\text { Serial Autoc. Test }\{\text { P-value }\}\end{array}$ & $\begin{array}{c}26.82\{0.000\} \\
2.95\{0.110\}\end{array}$ & $\begin{array}{c}99.47\{0.000\} \\
2.34\{0.150\}\end{array}$ \\
\hline
\end{tabular}

Source: Author's Computation (2020). Note: ${ }^{* * *} \mathbf{p}<0.01,{ }^{* *} \mathbf{p}<0.05,{ }^{*} \mathbf{p}<0.1$

Breusch and Pagan LM and Hausman Tests for Board Independence and Financial Performance Model 


\section{Main Model Eqn(1) Interpretation}

In column (1) of Table 3, F-statistics $=3.66$ and $\mathrm{P}$ - value $=0.036$ indicating a statistically significant model at $5 \%$ level. On the other hand, it indicates that the effect of Proportion of Executive to Non-executive directors (PENxD) and Frequency of Board meetings (FoBM) on Return on Equity are jointly statistically significant. Also, the adjusted R-squared value of 0.036 indicates that the explanatory variables jointly accounts for about $3.6 \%$ of variation in the Return on Equity (ROE). These are reliable evidences that the model is fit.

However, the separate effect of Proportion of Executive to Non-executive directors (PENxD) and Frequency of Board meetings (FoBM) on Return on Equity (ROE) is discussed accordingly. From the result in column (1) of Table 3, the coefficient of Proportion of Executive to Non-executive directors (PENxD), appears to be positive but statistically insignificant at $5 \%$ level of significance $[\beta=0.021 ; \mathrm{P}-$ value $>0.05]$. This means that the effect of PENxD on ROE during the period of this study is insignificant. On the contrary, the result shows that the coefficient of Frequency of Board meetings (FoBM) is negative and statistically significant at $5 \%$ level $[\beta=-0.136 ; \mathrm{P}-$ value $<0.05]$. This means that Frequency of Board meetings (FoBM) has significant effect on Return on Equity (ROE) of the selected listed banks in Nigeria.

\section{Main Model with control variable Eqn.(2)}

According to the result in Table 3, the computed F-statistics value $(24.10 ; \mathrm{P}-$ value $<0.05)$ in column (2) is found to be highly significant comparing it with the computed F-statistics value in column (1) of the Table. In other words, the result shows that our model is still statistically significant at 5\% level after introducing Capital Adequacy ratio (CAR), Liquidity ratio (LR), Firm Size (FS) and firm Age (Age) into the main model as control variables. This depicts that the effect of Proportion of Executive to Non-executive directors (PENxD), Frequency of Board meetings (FoBM), Capital Adequacy ratio (CAR), Liquidity ratio (LR), Firm Size (FS) and firm Age (Age) on Return on Equity (ROE) became more jointly statistically significant. Likewise, it is found that after adjusting the $\mathrm{R}^{2}$ value (Adjusted $\mathrm{R}$-squared) based on the number of independent variables in our the model, the explanatory power of the model improved as it increased to 0.100 in model (2) from 0.036 in model (1). This in other words mean that Proportion of Executive to Non-executive directors (PENxD), Frequency of Board meetings (FoBM), Capital Adequacy ratio (CAR), Liquidity ratio (LR), Firm Size (FS) and firm Age (Age) jointly explain about $10.0 \%$ of variations in the Return on Equity after controlling for Capital Adequacy ratio (CAR), Liquidity ratio (LR), Firm Size (FS) and firm Age (Age). Besides, the result shows that the coefficient of Proportion of Executive to Non-executive directors (PENxD) turns negative; though still insignificant while that of Frequency of Board meeting (FoBM) remains negative and statistically significant.

Decision: Going by the result of the regression analysis, most importantly the F- Statistic $=3.66(\mathrm{P}-\mathrm{value}=$ 0.046); Adjusted $\mathrm{R}^{2}=0.036$ and F-Statistic $=7.300(0.000)$; Adjusted $\mathrm{R}^{2}=0.100$

Thus, we conclude that there is significant effect of board independence (proportion of Executive to Nonexecutive directors and Frequency of meetings) on the financial performance of listed Banks in Nigeria and Capital Adequacy ratio, Liquidity ratio, firm size and firm age have significant controlling effect on board independence (proportion of Executive to Non-executive directors and Frequency of Board meetings) and the financial performances of listed Deposit Money Banks in Nigeria

Discussion of Findings: From the result of main pooled regression analysis, the findings revealed that positive and insignificant relationship exists between Proportion of Executive to Non-executive directors (PENxD) and Return on Equity (ROE) in model 1. This is consistent with the findings of Wang (2014) who conducted a metaempirical study on the relationship between independent directors and firm performance in listed Chinese companies after the independent director institution has been introduced from corporate America to corporate China. He found that the board independence has no significant impact on firm performance. On the contrary, this is not in line with the findings of Ongoso (2014) who explored the relationship between corporate board structure and financial performance of companies listed at Nairobi Securities Exchange. It was reported that there is strong positive association between board size and corporate financial performance. Also, we found that Frequency of Board meetings (FoBM) exhibits negative and significant relationship with Return on Equity (ROE) of the selected listed banks in Nigeria. This is not in tandem with the findings of Eluyela, Akintimehin, Okere, Ozordi, Osuma, Ilogho and Oladipo (2018) who examined the impact of board meeting frequency on firm performance of deposit money banks in Nigeria. They collected data from pages of annual reports of the deposit money banks listed on Nigeria stock exchange (NSE) market and employed a panel regression to test the significant association amid variables. They find positive association amid board meeting frequency and firm performance. On other hand, our findings is supported by the result of Ting, Kiong, Kweh \& Hoanh (2018) who investigated the effect of board meeting frequency on the financial performance of listed firms in a fiscal year. About 94 firms listed on Ho Chi Minh Stock Exchange from 2013 to 2015 were used and one of the financial performance measure used was returns on equity. They found a result that showed that board meeting frequency exerts a negative effect on the financial performance of the sample firms. Thus, they concluded that high board meeting frequency equates to low returns on equity. 
Test of Hypothesis Two $\left(\mathrm{H}_{02}\right)$

Research Hypothesis (Ho2):

i. Compliance with regulatory framework (committee meetings and Periodic reports) has no significant effect on financial performance of Deposit Money Banks listed in Nigeria

ii. Capital Adequacy ratio, Liquidity ratio, firm size and firm age have no significant controlling effect on Compliance with regulatory framework (committee meetings and Periodic reports) and the financial performances of listed Deposit Money Banks in Nigeria

Table 4: Compliance with CBN regulatory framework and Financial Performance

\begin{tabular}{|c|c|c|}
\hline VAR & $\begin{array}{c}\text { Pooled Regression wi } \\
\text { (1) } \\
\beta \text { (StdError) [t-stat] } \\
\text { \{p-value\} } \\
\end{array}$ & $\begin{array}{c}\text { Indard Error (Cluster) } \\
\text { (2) } \\
\beta \text { (StdError) [t-stat }] \\
\{\text { p-value }\} \\
\end{array}$ \\
\hline FoPR & $\begin{array}{c}0.051 * *(0.021)[2.406] \\
\{0.032\}\end{array}$ & $\begin{array}{c}0.028(0.026)[1.090] \\
\{0.296\}\end{array}$ \\
\hline FoCM & $\begin{array}{c}0.023(0.035)[0.671] \\
\{0.514\}\end{array}$ & $\begin{array}{c}-0.025(0.031)[-0.807] \\
\{0.434\}\end{array}$ \\
\hline CAR & & $\begin{array}{c}0.0002(0.000) 0.574 \\
(0.576)\end{array}$ \\
\hline LR & & $\begin{aligned} 0.226 * & (0.108)[2.098] \\
& \{0.056\}\end{aligned}$ \\
\hline FS & & $\begin{aligned} 0.034 * & (0.016)[2.160] \\
& \{0.050\}\end{aligned}$ \\
\hline Age & & $\begin{array}{c}-0.0003(0.001)[-0.355] \\
\{0.729\}\end{array}$ \\
\hline Constant & $\begin{array}{c}0.008(0.055)[0.144] \\
\{0.888\} \\
\end{array}$ & $\begin{array}{c}-0.669 * *(0.301)[-2.226] \\
\{0.044\}\end{array}$ \\
\hline $\begin{array}{l}\mathbf{N} \\
\text { R-squared } \\
\text { Adjusted R-squared } \\
\text { F-statistics }\{\text { P-value }\end{array}$ & $\begin{array}{c}140 \\
0.027 \\
0.013 \\
3.64\{0.047\}\end{array}$ & $\begin{array}{c}140 \\
0.088 \\
0.047 \\
27.19\{0.000\}\end{array}$ \\
\hline $\begin{array}{l}\text { LM Test }\{\text { P-value }\} \\
\text { Hausman Test }\{\text { P-value }\}\end{array}$ & $\begin{array}{l}0.36\{0.273\} \\
0.24\{0.888\}\end{array}$ & $\begin{array}{l}0.00\{1.000\} \\
1.96\{0.924\}\end{array}$ \\
\hline $\begin{array}{l}\text { Het. Test }\{\mathrm{P} \text {-value }\} \\
\text { Serial Autoc. Test }\{\mathrm{P} \text {-value }\}\end{array}$ & $\begin{array}{c}61.76\{0.000\} \\
5.11\{0.042\} \\
\end{array}$ & $\begin{array}{c}98.28\{0.000\} \\
4.26\{0.060\} \\
\end{array}$ \\
\hline
\end{tabular}

Source: Author's Computation (2020). Note: ${ }^{* * *} \mathrm{p}<0.01, * * \mathrm{p}<0.05,{ }^{*} \mathrm{p}<0.1$

\section{Main Model Eqn.(3) Interpretation}

Again, in column (1) of Table 4 , the F-statistics $=3.64$ and $\mathrm{P}-$ value $=0.047$ show a statistically significant model at $5 \%$ level. This means that the effect of Rendition of periodic reports (FoPR) and Number of times the risk management committee meets (FoCM) on Return on Equity are jointly statistically significant. Correspondingly, the adjusted R-squared value of 0.013 indicates that the explanatory variables jointly accounts for about $1.3 \%$ of variation in the Return on Equity (ROE). These strongly show that the model is fit.

Nevertheless, focusing on the individual effect of Rendition of periodic reports (FoPR) and Number of times the risk management committee meets (FoCM) on Return on Equity (ROE), the result in column (1) of Table 4 showed that the coefficient of Rendition of periodic reports (FoPR) is positive and statistically significant at $5 \%$ level of significance $[\beta=0.051 ; \mathrm{P}$ - value $<0.05]$. This means that the effect of FoPR on ROE during the period of this study is significant suggesting that Rendition of periodic reports (FoPR) is a determinant of performance in terms of Return on Equity. On the contrary, the result shows that the coefficient 
of Number of times the risk management committee meets (FoCM) is positive but statistically insignificant at $5 \%$ level $[\beta=0.023 ; \mathrm{P}-$ value $>0.05]$. This means the Number of times the risk management committee meets (FoCM) does not have a significant effect on Return on Equity (ROE) of the selected listed banks in Nigeria.

\section{Main Model with control variable Eqn.(4)}

From the result in Table 4, the computed F-statistics value $(27.19 ; \mathrm{P}$ - value $<0.05)$ in column $(2)$ is found to be highly significant compare to the computed F-statistics value in column (1) of the Table. In other words, the result shows that our model remains statistically significant at 5\% level after introducing Capital Adequacy ratio (CAR), Liquidity ratio (LR), Firm Size (FS) and firm Age (Age) into the main model as control variables. This means that the combine effect of Rendition of periodic reports (FoPR), Number of times the risk management committee meets (FoCM), Capital Adequacy ratio (CAR), Liquidity ratio (LR), Firm Size (FS) and firm Age (Age) on Return on Equity (ROE) turn out to be more statistically significant. Equally, it is found that the Adjusted R-squared value for the model is 0.047 . This means that the explanatory power of the model has improved as it hit 0.047 in model (4) from 0.013 in model (3). This in other words mean that Rendition of periodic reports (FoPR), Number of times the risk management committee meets (FoCM), Capital Adequacy ratio (CAR), Liquidity ratio (LR), Firm Size (FS) and firm Age (Age) jointly explain about 4.7\% of variations in the Return on Equity after controlling for Capital Adequacy ratio (CAR), Liquidity ratio (LR), Firm Size (FS) and firm Age (Age). As well, the result shows that the coefficient of Rendition of periodic reports (FoPR) remains positive; though significant while that of Number of times the risk management committee meets (FoCM) turn negative and still statistically insignificant.

Decisions: Based the result of the regression estimates, essentially the F- Statistic $=3.64(\mathrm{P}-$ value $=0.047)$; Adjusted $\mathrm{R}^{2}=0.013$ and F-Statistic $=27.19(0.000)$; Adjusted $\mathrm{R}^{2}=0.047$

Discussion of Findings: From the result of main pooled regression analysis, we found that Rendition of periodic reports (FoPR) is positively related to firm performance in terms of return on equity. However, we are unable to found any empirical study that uses rendition of period report for comparison. Furthermore, the study finds that Number of times the risk management committee meets (FoCM) is positive but insignificant related to firm financial performance. This failed to align with the findings of Mohammed, Basariah and Sitraselvi (2018) who examined the impact of risk management committee characteristics on the performance of listed financial service firms in Nigeria. To achieve the objective of the study, data were obtained from a sample of 45 financial service firms (banks and nonbanks) for the period of 2012 to 2016. They used Panel Corrected Standard Errors (PCSEs) regression model in testing the hypotheses developed in the study and they found that risk management committee meetings have a significant positive effect on firm performance.

\section{Test of Hypothesis Three $\left(\mathrm{H}_{03}\right)$}

Research Hypothesis $\left(\mathrm{H}_{03}\right)$ :

i. Risk management (portfolio at risk and Cost income ratio) has no significant effect on the financial performance of listed Deposit Money Banks in Nigeria.

ii. Capital Adequacy ratio, Liquidity ratio, firm size and firm age have no significant controlling effect on Risk management (portfolio at risk and Cost income ratio)) and the financial performances of listed Deposit Money Banks in Nigeria 
Table 5: Risk management and Financial Performance

\begin{tabular}{|c|c|c|}
\hline VAR & $\begin{array}{c}\text { Pooled Regression wit } \\
\text { (1) } \\
\beta \text { (StdError) [t-stat }] \\
\{p \text {-value }\} \\
\end{array}$ & $\begin{array}{c}\text { andard Error (Cluster) } \\
\text { (2) } \\
\beta \text { (StdError) }[t \text {-stat }] \\
\{p \text {-value }\} \\
\end{array}$ \\
\hline NPL & $\begin{array}{c}-0.144(0.103)[-1.404] \\
\{(0.184)\}\end{array}$ & $\begin{array}{c}-0.036(0.130)[-0.281] \\
\{(0.783\}\end{array}$ \\
\hline CIR & $\begin{array}{c}-0.256 * *(0.093)[-2.742] \\
\{0.017\}\end{array}$ & $\begin{array}{c}-0.219 * * \\
\{0.082)[-2.653] \\
\{0.020\}\end{array}$ \\
\hline CAR & & $\begin{array}{c}0.0001(0.003)[0.288] \\
\{0.778\}\end{array}$ \\
\hline LR & & $\begin{aligned} & 0.220 *(0.110)[1.998] \\
&\{0.067\}\end{aligned}$ \\
\hline FS & & $\begin{array}{c}0.030 *(0.015)[1.965] \\
\{0.071\}\end{array}$ \\
\hline Age & & $\begin{array}{c}-0.0003(0.0005)[-0.540] \\
\{0.598\}\end{array}$ \\
\hline Constant & $\begin{array}{c}0.274 * * *(0.069)[3.972] \\
\{0.002\} \\
\end{array}$ & $\begin{array}{c}-0.436(0.320)[-1.366] \\
\{0.195\} \\
\end{array}$ \\
\hline $\begin{array}{l}\mathbf{N} \\
\text { R-squared } \\
\text { Adjusted R-squared } \\
\text { F-statistics \{P-value\} }\end{array}$ & $\begin{array}{c}140 \\
0.083 \\
0.049 \\
4.433\{0.034\}\end{array}$ & $\begin{array}{c}140 \\
0.132 \\
0.100 \\
20.82\{0.000\}\end{array}$ \\
\hline $\begin{array}{l}\text { LM Test }\{\text { P-value }\} \\
\text { Hausman Test }\{P \text {-value }\}\end{array}$ & $\begin{array}{c}0.00\{1.000\} \\
9.16\{0.28\}\end{array}$ & $\begin{array}{l}0.00\{1.000\} \\
3.97\{0.680\}\end{array}$ \\
\hline $\begin{array}{l}\text { Het. Test }\{\mathrm{P} \text {-value }\} \\
\text { Serial Autoc. Test }\{\mathrm{P} \text {-value }\}\end{array}$ & $\begin{array}{l}66.75\{0.000\} \\
4.868\{0.046\} \\
\end{array}$ & $\begin{array}{c}96.00\{0.000\} \\
3.15\{0.099\}\end{array}$ \\
\hline
\end{tabular}

Source: Author's Computation (2020). Note: ${ }^{* * *} \mathbf{p}<0.01,{ }^{* *} \mathbf{p}<0.05,{ }^{*} \mathbf{p}<0.1$

\section{Main Model Eqn.(5) Interpretation}

As in column (1) of Table 5, the F-statistics $=4.43$ and $\mathrm{P}$ - value $=0.034$ showed a statistically significant model at $5 \%$ level. This means that the effect of Ratio of non-performing loans to total loans (NPL) and Cost to income ratio (CIR) on Return on Equity are jointly statistically significant. Accordingly, the adjusted R-squared value of 0.049 indicates that the explanatory variables jointly accounts for about $4.9 \%$ of variances in the Return on Equity (ROE). These strongly show that the model is fit.

All the same, focusing on the distinct effect of Ratio of non-performing loans to total loans (NPL) and Cost to income ratio (CIR) on Return on Equity (ROE), the result in column (1) of Table 5 showed that the coefficient of Ratio of non-performing loans to total loans (NPL) is negative and statistically insignificant at $10 \%$ level of significance $[\beta=-0.144 ; \mathrm{P}-$ value $>0.05]$. This means that the effect of NPL on ROE during the period of this study is not significant suggesting that Ratio of non-performing loans to total loans (NPL) is not a driver of performance in terms of Return on Equity. Similarly, the result showed that the coefficient of Cost to income ratio (CIR) is negative and statistically significant at $5 \%$ level $[\beta=-0.256 ; \mathrm{P}-$ value $<0.05]$. This means the Cost to income ratio (CIR) have a significant effect on Return on Equity (ROE) of the selected listed banks in Nigeria.

Main Model with control variable Eqn.(6)

From the result in Table 5, the estimated F-statistics value $(20.82 ; \mathrm{P}-$ value $<0.05)$ in column $(2)$ is seen to be highly significant compare to the computed F-statistics value in column (1) of the Table. This means that our 
model remains statistically significant at 5\% level even after introducing Capital Adequacy ratio (CAR), Liquidity ratio (LR), Firm Size (FS) and firm Age (Age) into the main model as control variables. This means that the combine effect of Ratio of non-performing loans to total loans (NPL), Cost to income ratio (CIR), Capital Adequacy ratio (CAR), Liquidity ratio (LR), Firm Size (FS) and firm Age (Age) on Return on Equity (ROE) turn out to be more statistically significant. In the same way, it is seen that the Adjusted R-squared value for the model is 0.100 . This means that the explanatory power of the model has improved as it reached 0.100 in model (6) from 0.049 in model (5). This in other words mean that Ratio of non-performing loans to total loans (NPL), Cost to income ratio (CIR), Capital Adequacy ratio (CAR), Liquidity ratio (LR), Firm Size (FS) and firm Age (Age) jointly explain about $10.0 \%$ of variations in the Return on Equity after controlling for Capital Adequacy ratio (CAR), Liquidity ratio (LR), Firm Size (FS) and firm Age (Age). As well, the result shows that the coefficient of Ratio of non-performing loans to total loans (NPL) remains positive; though significant while that of Cost to income ratio (CIR) turn negative and still statistically insignificant.

Decisions: Based the result of the regression estimates, essentially the F- Statistic $=4.43(\mathrm{P}-$ value $=0.034)$; Adjusted $\mathrm{R}^{2}=0.049$ and F-Statistic $=20.82(0.000)$; Adjusted $\mathrm{R}^{2}=0.100$

Therefore, we concluded that Risk management (portfolio at risk and Cost income ratio) has no significant effect on the financial performance of listed Deposit Money Banks in Nigeria and Capital Adequacy ratio, Liquidity ratio, firm size and firm age have no significant controlling effect on Risk management (portfolio at risk and Cost income ratio)) and the financial performances of listed Deposit Money Banks in Nigeria.

Discussion of Findings: The findings from the regression result showed that there is negative and statistically insignificant relationship between the ratio of non-performing loans to total loans (NPL) and Return on Equity (ROE). This result is not supported by the findings of Ekinci and Poyraz (2019). In their study, they analyze the impact of credit risk on banks performance using secondary data collected from the statistical report of the Banks Association of Turkey with another three panels' data are considered respectively state-owned banks, privately-owned banks and foreign banks in order to compare banks according to their ownership structure. According to them, Return on Asset (ROA) and Return on Equity (ROE) were used as proxies for financial performance indicators while Non-Performing Loans (NPLs) was used as credit risk indicators. At last, they found that there is a negative and significant relationship between credit risk (captured Non-Performing Loans (NPLs)) and ROE. Conversely, the finding of Adebisi and Okike (2015) is in support of our findings. To examine the impact of non-performing loans on firms' profitability of banks in Nigeria, the study made use of secondary data obtained from the Annual Report and Statement of Accounts of the NDIC for a period of seven (7) years (2006- 2012). They analyzed the data using the regression approach and result show there is no significant relationship between the Non-performing Loans (NPL) and Return on Equity (ROE) of Nigerian Banks. Also, Cost to income ratio (CIR) is found to be negatively and significantly related to Return on Equity (ROE). This is in tandem with the findings of Mathuva (2009) who noted that CIR is inversely related to bank profitability measures (ROA and ROE). According to him, the study provides evidence that supports the Central Bank of Kenya's move to gradually raise bank capital levels by 2012 and to tightly monitor the operations of banks so as to ensure that Kenyan banks are more efficient in their operations while at the same time being profitable. With the present global credit crunch, capital adequacy and the cost-income ratio being critical for banks. The study was carried out to examine the relationship between CIR and other variables and profitability. Using the return on assets and the return on equity as proxies for bank profitability for the period 1998 to 2007.

\section{Test of Hypotheses Four ( $\left.\mathrm{H}_{04}\right)$ Research Hypothesis ( $\left.\mathbf{H}_{04}\right)$ :}

i. There is no significant effect of internal communications (disclosures and information communication) in the organization on the financial performances of listed Deposit Money Banks in Nigeria

ii. Capital Adequacy ratio, Liquidity ratio, firm size and firm age have no significant controlling effect on internal communication of information and the financial performances of listed Deposit Money Banks in Nigeria 
Table 6: Internal Communication of Information and Financial Performance

\begin{tabular}{|c|c|c|}
\hline VAR & $\begin{array}{l}\text { Pooled Regression wi } \\
\text { (1) } \\
\beta \text { (StdError) }[\mathrm{t}-\text { stat }] \\
\quad\{\mathrm{p} \text {-value }\} \\
\end{array}$ & $\begin{array}{c}\text { andard Error (Cluster) } \\
\text { (2) } \\
\beta \text { (StdError) }[\mathrm{t}-\mathrm{stat}] \\
\{\mathrm{p} \text {-value }\} \\
\end{array}$ \\
\hline $\mathrm{D}$ & $\begin{array}{c}0.820 * *(0.345)[2.377] \\
\{0.033\}\end{array}$ & $\begin{aligned} 0.873 * & (0.435)[2.005] \\
& \{0.066\}\end{aligned}$ \\
\hline IC & $\begin{array}{c}0.098(0.078)[1.253] \\
\{0.232\}\end{array}$ & $\begin{array}{c}0.110(0.102)[1.081] \\
\{0.299\}\end{array}$ \\
\hline CAR & & $\begin{array}{c}0.001(0.001)[1.337] \\
\{0.204\}\end{array}$ \\
\hline LR & & $\begin{array}{c}0.180(0.129)[1.401] \\
\{0.185\}\end{array}$ \\
\hline FS & & $\begin{array}{c}-0.004(0.024)[-0.161] \\
\{0.874\}\end{array}$ \\
\hline Age & & $\begin{array}{c}-0.002(0.002)[-1.023] \\
\{0.325\}\end{array}$ \\
\hline Constant & $\begin{array}{c}-0.758 * *(0.341)[-2.223] \\
\{0.045\}\end{array}$ & $\begin{array}{c}-0.740 * * *(0.245)[-3.020] \\
\{0.010\} \\
\end{array}$ \\
\hline $\begin{array}{l}\mathbf{N} \\
\text { R-squared } \\
\text { Adjusted R-squared } \\
\text { F-statistics \{P-value }\end{array}$ & $\begin{array}{c}140 \\
0.146 \\
0.134 \\
3.65\{0.045\}\end{array}$ & $\begin{array}{c}140 \\
0.197 \\
0.161 \\
22.86\{0.000\}\end{array}$ \\
\hline $\begin{array}{l}\text { LM Test }\{\text { P-value }\} \\
\text { Hausman Test }\{\text { P-value }\}\end{array}$ & $\begin{array}{l}0.72\{0.199\} \\
0.33\{0.846\}\end{array}$ & $\begin{array}{l}0.42\{0.259\} \\
7.99\{0.239\}\end{array}$ \\
\hline $\begin{array}{l}\text { Het. Test }\{\mathrm{P} \text {-value }\} \\
\text { Serial Autoc. Test }\{\mathrm{P} \text {-value }\}\end{array}$ & $\begin{array}{c}30.66\{0.000\} \\
1.996\{0.181\}\end{array}$ & $\begin{array}{c}81.75\{0.000\} \\
1.33\{0.269\}\end{array}$ \\
\hline
\end{tabular}

Source: Author's Computation (2020). Note: ${ }^{* * *} \mathrm{p}<0.01,{ }^{* *} \mathrm{p}<0.05,{ }^{*} \mathrm{p}<0.1$

Main Model Eqn. (7) Interpretation

As in column (1) of Table 6 , the F-statistics $=3.65$ and $\mathrm{P}$ - value $=0.045$ show a statistically significant model at $5 \%$ level. This means that Disclosures of accounting policies in the financial statement (D) and Frequency of monitoring internal control deficiencies by the audit committee (IC) are jointly statistically significant in explaining variations in on Return on Equity. Accordingly, the adjusted R-squared value of 0.117 indicates that the explanatory variables jointly explain about $13.4 \%$ of variances in the Return on Equity (ROE). These show that the model is adequate.

Based on the distinct effect of Disclosures of accounting policies in the financial statement (D) and Frequency of monitoring internal control deficiencies by the audit committee (IC) on Return on Equity (ROE), the result in column (1) of Table 6 shows that the coefficient of Disclosures of accounting policies in the financial statement (D) is positive and statistically significant at $5 \%$ level of significance $[\beta=0.820 ; \mathrm{P}-$ value $<$ 0.05]. This means that the effect of $\mathrm{D}$ on ROE during the period of this study is significant suggesting that Disclosures of accounting policies in the financial statement (D) is a determinant of performance in terms of Return on Equity. Similarly, the result shows that the coefficient of Frequency of monitoring internal control deficiencies by the audit committee (IC) is positive but statistically insignificant at $5 \%$ level $[\beta=0.098 ; \mathrm{P}-$ value $>0.05]$. This means the Frequency of monitoring internal control deficiencies by the audit committee (IC) have no significant effect on Return on Equity (ROE) of the selected listed banks in Nigeria. 
Main Model with control variable Eqn. (8)

Again, from the result in Table 6, the estimated F-statistics value $(22.8 ; \mathrm{P}$ - value $<0.05)$ in column $(2)$ is seen to be highly significant compare to the computed F-statistics value in column (1) of the Table. This means that our model remains statistically significant at 5\% level even after introducing Capital Adequacy ratio (CAR), Liquidity ratio (LR), Firm Size (FS) and firm Age (Age) into the main model as control variables. This means that the joint effect of Disclosures of accounting policies in the financial statement (D), Frequency of monitoring internal control deficiencies by the audit committee (IC), Capital Adequacy ratio (CAR), Liquidity ratio (LR), Firm Size (FS) and firm Age (Age) on Return on Equity (ROE) turn out to be more statistically significant. In the same way, it is seen that the Adjusted R-squared value for the model is 0.161 . This means that the explanatory power of the model becomes better as it reached $0.161 \mathrm{in}$ model (8) from 0.134 in model (7). This in other words mean that Disclosures of accounting policies in the financial statement (D), Frequency of monitoring internal control deficiencies by the audit committee (IC), Capital Adequacy ratio (CAR), Liquidity ratio (LR), Firm Size (FS) and firm Age (Age) jointly explain about 16.1\% of variations in the Return on Equity after controlling for Capital Adequacy ratio (CAR), Liquidity ratio (LR), Firm Size (FS) and firm Age (Age). As well, the result shows that the coefficient of Disclosures of accounting policies in the financial statement (D) remains positive; though significant and that of Frequency of monitoring internal control deficiencies by the audit committee (IC) remains positive but still statistically insignificant.

Decisions: In the result of the regression estimates, essentially the F- Statistic $=3.65(\mathrm{P}-$ value $=0.045)$; Adjusted $\mathrm{R}^{2}=0.134$ and F-Statistic $=22.86(0.000)$; Adjusted $\mathrm{R}^{2}=0.161$

Therefore, we conclude that there is significant effect of internal communications (disclosures and information communication) in the organization on the financial performances of listed Deposit Money Banks in Nigeria and Capital Adequacy ratio, Liquidity ratio, firm size and firm age have no significant controlling effect on internal communication of information and the financial performances of listed Deposit Money Banks in Nigeria.

Discussion of Findings: Also, the study found that Disclosures of accounting policies in the financial statement (D) is positive and statistically significant. Ojeka, Mukoro and Kanu (2015) found similar evidence when the relationship between financial reporting disclosures in annual reports and the performance of listed manufacturing companies in Nigeria between 2005 and 2009 was investigated empirically. In their study, they found that the results showed that there is a significant relationship between financial reporting disclosures and financial performance However, the finds that Frequency of monitoring internal control deficiencies by the audit committee (IC) is positive but not statistically significant.

\section{Conclusion and Recommendations}

The study therefore based on the findings obtained above concluded that there is significant effect of board independence on the financial performance of listed Banks in Nigeria and Capital Adequacy ratio, Liquidity ratio, firm size and firm age had significant controlling effect on board independence and the financial performances of listed Deposit Money Banks in Nigeria. Also the study also confirmed that Compliance with regulatory framework had significant effect on financial performance of Deposit Money Banks listed in Nigeria while Capital Adequacy ratio, Liquidity ratio, firm size and firm age had no significant controlling effect on Compliance with regulatory framework and the financial performances of listed Deposit Money Banks in Nigeria.

The study also concluded that Risk management had no significant effect on the financial performance of listed Deposit Money Banks in Nigeria and Capital Adequacy ratio, Liquidity ratio, firm size and firm age had no significant controlling effect on Risk management and the financial performances of listed Deposit Money Banks in Nigeria. More so, the study also concluded that there is significant effect of internal communications in the organization on the financial performances of listed Deposit Money Banks in Nigeria and Capital Adequacy ratio, Liquidity ratio, firm size and firm age have no significant controlling effect on internal communication of information and the financial performances of listed Deposit Money Banks in Nigeria.

The following recommendations were given:

i. The banks must have an independent Board of Directors and its committee as a Corporate Governance regulatory requirement. Besides this, an independent audit department that is well trained and staffed should be set in all the branches of the banks to facilitate effective implementation of internal controls.

ii. Banks should have in place an information system that facilitates relaying of timely, relevant and reliable information to stakeholders and free upward and downward flow of information between management and employees. Ethical values should be upheld in decision-making, integrity and competence enhanced. Above all the management should ensure an atmosphere of mutual trust exist within their banks. Banks should design and organize for constant seminars and workshops to train its management and employees in finance, accounting, and internal audit departments 
pertaining Internal Controls, policies and procedures in order to enhance their professional skills and practices.

iii. All forms ofregulatory policies should be adhered to and review adequately in line with the financial regulatory framework on a timely basis to the appropriate level of management. This would help solve the issue of supervisors relaxing while performing their duties

iv. The management of deposit money banks should ensure financial reporting, legal and regulatory requirements are met by the banks and transparent periodic reporting to stakeholders on Risk Management and Internal Controls is undertaken.

v. Deposit money banks need to strengthen the monitoring of banks operation on capital adequacy as needs to scrutinize the level of loan loss reserves within the organization.

\section{References}

Adebisi J. F. \& Okike B. M. (2015). The Impact of Non-Performing Loans on Firm Profitability: A Focus on the Nigerian Banking Industry. American Research Journal of Business and Management, 1 (4), 1-7

Ashbaugh-Skaife, H., D. W. Collins, W. R. Kinney, Jr., and R. LaFond. 2009. The effect of internal control deficiencies on firm risk and cost of equity. Journal of Accounting Research, 47 (1), 1-43.

Arslan, O., Eksi, C., and Karan, M.B. (2010). Board structure and corporate performance, Managing Global Transitions, 8(10), 3-22. http://www.fm-kp.si/zalozba/ISSN/1581-6311/8_003-022.pdf

Bagh, T., Muhamad, A.K., and Razzaq, S (2017). The Impact of Exchange Rate Volatility on Stock Index: Evidence from Pakistan Stock Exchange (PSX). International Journal of Academic Research in Accounting, Finance and Management Sciences. http://hrmars.com/hrmars_papers/Article_08_The_Impact_of_Exchange_Rate_Volatility.pdf

Batchimeg, B. (2017). Financial Performance Determinants of Organizations: The Case of Mongolian Companies. Journal of Competitiveness. 9(3), 22-33. DOI: 10.7441/joc.2017.03.02.

CBN (2010). Annual Statistical Bulletin. Lagos, Nigeria.

COSO. (2011). Internal Control-Integrated Framework.

COSO. (2013). Internal Control-Integrated Framework.

Danoshana ,S., and Ravivathani ,T. (2013). The impact of the corporate governance on firm performance: A study on financial institutions in Sri Lanka. Merit Research Journal of Accounting, Auditing, Economics and Finance, 1(6), 118-

121. (http://meritresearchjournals.org/aaef/Content/2013/December/Danoshana\%20and\%20Ravivathani.pd $\mathrm{f}$

Eluyela, D.E., Akintimehin, O.O., Okere, W., Ozordi, E., Osuma, G.O., Ilogho, S.O. \& Oladipo, O.A. (2018). Board meeting frequency and firm performance: examining the nexus in Nigerian deposit money banks. Heliyon, 4(10), e00850, 1-14.

Hammersley, J. S., L. A. Myers, and C. Shakespeare. 2008. Market reactions to the disclosure of internal control weaknesses and to the characteristics of those weaknesses under Section 302 of the Sarbanes-Oxley Act of 2002. Review of Accounting Studies 13 (1): 141-165.

Kieso, D. E., Weygandt, J. J., and Warfield, T. D. (2012). Intermediate accounting (14 th Ed.). Hoboken, NJ: John Wiley and Sons.

Kinyua, J. K., Gakure, R., Gekara, M., and Orwa, G. (2015). Effect of Internal Control Environment on the Financial Performance of Companies Quoted in the Nairobi Securities Exchange.

Koch, Timothy W. \& MacDonald, Scott S. (2002). Bank Management. $5^{\text {th }}$ edition.

Mathuva D. M. (2009). Capital Adequacy, cost Income Ratio and the Performance of Commercial Banks: The Kenyan Scenario. The International Journal of Applied Economics and Finance, 3(2), 35-47.

Njogo, B.O. (2012). Risk management in the Nigerian banking industry. Kuwait Chapter of Arabian Journal of Business and Management Review, 1(10), 100-109.

Ojeka S. A., Mukoro D. O., Kanu C. (2015). Does Financial Reporting Disclosures Enhance Firm Financial Performance in the Nigerian Manufacturing Companies? Mediterranean Journal of Social Sciences, 6(6), $332-338$

Ongoso, J. (2014). The relationship between corporate board structure and financial performance of companies listed at Nairobi securities exchange. University of Nairobi. Unpublished project.

Payal and Singh, S. (2017). Board of Directors and Corporate Performance: Evidence from India. International Journal of Commerce and Management. 11(1), 11-28. http://acfa.apeejay.edu/docs/volumes/envision2017/envision-paper-08-vol-11-(2017).pdf

Sanusi, L. S. (2010). CBN Governor, C.O.N. Global financial meltdown and the reforms in the Nigerian banking sector. Being the full text of a public lecture delivered at the convocation square. Bauchi: Abubakar Tafawa Balewa University.

Wang, W. (2014). Independent directors and Coporate performance in China: a meta-empirical study. 